\title{
FAKTOR-FAKTOR YANG MEMPENGARUHI VOLUME BERAS IMPOR DI JAWA TIMUR
}

\author{
Ike Susanti \\ Universitas Islam Lamongan
}

\begin{abstract}
ABSTRAK
Provinsi Jawa Timur sebagai salah satu penyangga pangan nasional memiliki tingkat fluktuasi produksi beras. luas lahan yang tersedia adalah tetap, bahkan cenderung menurun sebagai fungsi beralih ke non-pertanian sampai akhirnya menjadi salah satu hal yang menyebabkan munculnya permintaan untuk impor beras. teknik analisis menggunakan beberapa uji regresi linier dan uji hipotesis menggunakan uji $F$ dan uji t. studi populasi adalah variabel (X1), Produksi Padi (X2), Lokal Harga Beras (X3), Harga Jagung (X4), harga singkong (X5) dan Volume Beras Impor (Y). Sampel dalam penelitian ini adalah kegiatan beras yang dilakukan oleh pemerintah Provinsi Jawa Timur selama 15 tahun terakhir. Berdasarkan penelitian ini, dapat disimpulkan bahwa ada perkembangan populasi, produksi beras, harga beras lokal, harga jagung dan ubi kayu harga dan volume beras impor di Jawa Timur. Variabel jumlah penduduk, harga jagung dan singkong harga tidak berpengaruh secara signifikan terhadap volume beras impor, produksi beras hanya dan harga beras lokal yang memiliki dampak yang signifikan terhadap volume impor beras dan di antara penduduk, produksi beras, harga beras lokal, harga jagung dan harga singkong, harga beras lokal yang memiliki pengaruh dominan terhadap volume beras impor di Jawa Timur.
\end{abstract}

Kata kunci: Populasi, Produksi Padi, Lokal Harga Beras, Harga harga Jagung dan Ubi Kayu dan volume beras impor

\section{PENDAHULUAN}

Ketahanan pangan suatu negara dapat dikatakan baik jika semua penduduknya setiap saat dapat memiliki akses terhadap makanan dalam volume dan mutu yang sesuai bagi suatu kehidupan yang produktif dan sehat. Akses setiap individu terhadap terhadap pangan yang cukup merupakan hak azasi manusia yang berlaku secara universal. Oleh sebab itu, sampai sejauh mana suatu negara menghormati hak azasi warganya yang dapat diukur dari ketahanan pangan yang dimilikinya, bahkan ketahanan pangan dijadikan salah satu indikator penting bagi keberhasilan pembangunan nasional (Saragih, 2001).

Undang-undang no 7 tahun 1996 tentang pangan mengamanatkan bahwa pemerintah bersama masyarakat bertanggung jawab untuk mewujudkan ketahanan pangan. Untuk itu pemerintah 
wajib menyelenggarakan peraturan, pembinaan, pengendalian dan pengawasan terhadap ketersediaan pangan yang cukup, baik jumlah dan mutunya, aman, bergizi, beragam, merata dan terjangkau oleh daya beli masyarakat. Selanjutnya masyarakat berperan dalam menyelenggarakan produksi dan penyediaan, perdagangan dan distribusi serta sebagai konsumen yang berhak memperoleh pangan yang aman dan bergizi (Lubis, 2005).

Provinsi Jawa Timur mempunyai sumber daya alam cukup potensial, sudah sewajarnya harus mampu mencukupi kebutuhan pangan bagi penduduknya, karena pengan mempengaruhi kebutuhan masyarakat, berbangsa dan bernegara baik dalam bidang ekonomi, politik, sosial budaya dan hankam. Ketersediaan pangan secara umum bersumber dari produksi lokal, pasokan dari luar kota, luar negeri (Import) serta dukungan stok atau cadangan yang diharapkan mampu memenuhi kebutuhan masyarakat (Lubis, 2005).

Keputusan pemerintah mengimpor besar dengan alasan menekan harga beras dan mengamankan stok nasional merupakan langkah yang kurang tepat karena naiknya harga beras bukan disebabkan oleh persediaan yang menipis, kenaikan justru disebabkan oleh melonjaknya ongkos produksi akibat naiknya harga bahan bakar minyak (Kompas, 11 Januari 2011).Untuk menjaga harga beras agar tetap terkendali, maka produksi nasional harus tetap seimbang dengan konsumsi nasional. Terjadinya peningkatan impor hanya akan memicu kenaikan harga beras internasional, karena itu dalam jangka panjang akan semakin besar pula ketergantungan terhadap impor beras dan semakin tidak terjamin pasokan beras secara murah (Sugema, 2006).

Provisinsi Jawa Timur sebagai salah satu penyangga pangan nasional mempunyai tingkat produksi padi yang berfluktuasi dari waktu ke waktu. Produksi pada dasarnya merupakan hasil kali luas panen dengan produktivitas per hektare lahan, sehingga seberapa besar produksi suatu wilayah sangat tergantung berapa luas panen pada tahun yang bersangkutan atau berapa tingkat produktivitasnya. Luas lahan yang tersedia bersifat tetap, bahkan cenderung berkurang karena beralih fungsi ke non pertanian hingga lambat laun berperan sebagai salah satu hal yang mengakibatkan munculnya permintaan impor beras. Berdasarkan latar belakang 
yang telah di uraikan diatas, maka penulis untuk melakukan peneltian dengan judul "faktor-faktor yang mempengaruhi volume beras impor di Jawa Timur" agar dapat diketahui dengan jelas alasan, sebab serta akibat yang terjadi terhadap ketahanan pangan di Provinsi Jawa Timur.

\section{TINJAUAN PUSTAKA}

\subsection{Ketahanan Pangan}

Pengertian pangan sendiri memiliki dimensi yang luas. Mulai dari pangan yang esensial bagi kehidupan manusia yang sehat dan produktif (keseimbangan kalori, karbohidrat, protein, lemak, vitamin, serat, dan zat esensial lain); serta pangan yang dikonsumsi atas kepentingan sosial dan budaya, seperti untuk kesenangan, kebugaran, kecantikan dan sebagainya. Dengan demikian, pangan tidak hanya berarti pangan pokok, dan jelas tidak hanya berarti beras, tetapi pangan yang terkait dengan berbagai hal lain. Pangan merupakan salah satu kebutuhan dasar manusia yang merupakan bagian dari Hak Asasi Manusia (HAM), sebagaimana tertuang dalam Deklarasi Hak Asasi Manusia (HAM) Universal (Universal Declaration of Human Right) tahun 1948, serta UU NO 7 Tahun 1996 tentang Pangan.

Sementara menurut Badan POM, pangan adalah makanan untuk dikonsumsi yang tidak hanya berupa beras, tapi juga sayur-mayur, buahbuahan, daging baik unggas maupun lembu, ikan, telur, juga air. Ketahanan pangan menurut UU NO 7 tahun 1996 Tentang Pangan Pasal 1 ayat 17 adalah kondisi terpenuhinya pangan yang cukup, baik secara jumlah maupun mutu, serta aman, merata, dan terjangkau. Ketahanan pangan dapat pula didefinisikan sebagai situasi dimana dalam segala waktu memiliki kecukupan jumlah atas pangan yang aman dan bergizi demi kehidupan yang sehat dan aktif. Secara umum, ketahanan pangan adalah adanya jaminan bahwa kebutuhan pangan dan gizi setiap penduduk adalah sebagai syarat utama dalam mencapai derajat kesehatan dan kesejahteraan yang tercukupi (Sitanggang dan Marbun, 2007).

\subsection{Ketersediaan Pangan (Beras)}

Menurut undang-undang RI nomor 7 tahun 1996 mendefinisikan ketahanan pangan (Food Security) sebagai kondisi terpenuhinhya pangan bagi rumah tangga yang tercermin dari tersedianya 
pangan yang cukup, baik jumlah maupun mutunya, aman, merata dan terjangkau (Lubis, 2005). Sedangkan menurut Peraturan Pemerintah (PP) No. 68 tahun 2002 Ketersediaan pangan adalah tersedianya pangan dari hasil produksi dalam negeri dan/atau sumber lain. Pasal 2 PP No. 68 tahun 2002 Pasal 2 Penyediaan pangan diselenggarakan untuk mewujudkan penyediaan pangan dilakukan dengan :

1. Mengembangkan sistem produksi pangan yang bertumpu pada sumberdaya, kelembagaan dan budaya lokal.

2. Mengembangkan efisiensi sistem usaha pangan.

3. Mengembangkan teknologi produksi pangan.

4. Mengembangkan sarana dan prasarana produksi pangan

5. Mempertahankan dan mengembangkan lahan produktif Ketersediaan pangan menurut Peraturan Pemerintah (PP) No.68 tahun 2002 tentang Ketahanan Pangan tersebut harus diutamakan bersumber dari dalam negeri. Pasal 3 peraturan pemerintah tersebut menyatakan bahwa Sumber penyediaan pangan berasal dari produksi pangan dalam negeri, cadangan pangan, dan pemasukan pangan. Pemasukan pangan dilakukan apabila produksi pangan dalam negeri dan cadangan pangan tidak mencukupi kebutuhan konsumsi dengan tetap memperhatikan kepentingan produksi dalam negeri. Penyediaan produksi pangan dalam negeri untuk makanan pokok umumnya dilakukan dengan melakukan swasembada pangan.

\subsection{Barang Substitusi Pengganti Beras}

Barang subtitusi merupakan suatu barang yang keberadaannya dapat menggantikan posisi barang lainnya sehingga nilai gunanya masih sama dengan yang digantikan (Kurniawati dan Kamsiati, 2010). Dewasa ini, dalam kondisi peliknya masalah perberasan di Indonesia khususnya di Jawa Timur, munculah beberapa komoditi yang dapat menjadi barang pengganti beras. Barang tersebut yang banyak beredar di Jawa Timur adalah Jagung dan Ubi Kayu. Lebih lanjut deskripsi mengenai dua barang subtitusi tersebut akan di jabarkan di bawah ini :

1. Jagung

Jagung merupakan salah satu tanaman serealia yang memiliki kandungan gizi dan serat kasar yang cukup memadai untuk digunakan 
sebagai bahan pangan pengganti beras. Jagung selain digunakan sebagai bahan pangan juga banyak digunakan sebagai bahan pakan ternak dan bahan baku produk industri. Haryono (2007) menyatakan bahwa peran jagung sebenarnya selain sebagai sebagai bahan baku industri juga masih berfungsi sebagai penopang kebutuhan akan bahan pangan, dimana diperkirakan lebih dari $45 \%$ kebutuhan jagung dalam negeri digunakan untuk pakan sedangkan untuk konsumsi pangan hampir sekitar $40 \%$ dan selebihnya digunakan untuk benih. Hal ini menyebabkan kebutuhan akan jagung terus mengalami peningkatan mengingat perkembangan sektor peternakan yang diiringi dengan peningkatan industri pangan dan pakan.

\section{Ubi Kayu}

Ubi kayu selama ini sudah banyak diolah menjadi berbagai macam produk makanan, baik makanan setengah jadi maupun makan jadi. Masyarakat sebesarnya juga sudah mengetahui cara mengolah ubi kayu agar dapat menjadi bahan makanan pengganti beras. Ubi kayu memiliki keunggulan berdasarkan aspek ketersediaan dan nutrisi. Keunggulan ini dapat menjadi faktor pendorong diversifikasi pangan dengan ubi kayu sebagai sumber alternarif utama (Kurniawati dan Kamsiati, 2010).

\subsection{Peran Beras}

Beras merupakan makanan pokok bagi masyarakat Indonesia. Menurut Suryana dan Mardianto (2001) beras mempunyai peran yang strategis dalam memantapkan ketahanan pangan, ketahanan ekonomi dan stabilitas politik nasional. Masyarakat masih tetap menghendaki adanya pasokan dan harga beras yang stabil, tersedia sepanjang waktu terdistribusi secara merata dan dengan harga terjangkau. Kondisi ini menunjukan bahwa beras masih menjadi komoditas strategis secara politis.

Beras memiliki karakteristik menarik antara lain: (1) 90 persen produksi dan konsumsi beras dilakukan di Asia (2) pasar beras dunia sangat rendah, yaitu hanya empat sampai dengan lima persen dari total produksi, berbeda dengan komoditas tanaman pangan lainnya seperti gandum, jagung dan kedelai yang masing-masing mencapai 20 persen, 15 persen, dan 30 persen dari total produksi : (3) harga beras sangat tidak stabil dibanding dengan produk lainnya (4) 80 persen perdagangan beras dikuasai oleh enam negara, yaitu Thailand, Amerika Serikat, 
Vietnam, Pakistan, Cina, dan Myanmar

(5) struktur pasar oligopolistik

Indonesia merupakan negara net importir sejak tahun 1998 dan (7) sebagian besar negara di Asia umumnya beras diperlakukan sebagai wage goods dan political goods (Suryana dan Mardianto, 2001).

\subsection{Kebijakan Beras Nasional}

Menurut Firdaus dan Prawiranegara (2008) kebijakan adalah suatu peraturan yang telah dirumuskan dan disetujui untuk dilaksanakan yang berguna untuk mempengaruhi suatu keadaan. Kebijakan berguna sebagai alat pemerintah untuk campur tangan dalam mempengaruhi perubahan secara sektoral pada masyarakat, begitu pula termasuk di dalamnya kebijakan pada sektor pertanian. Berdasarkan Inpres No.2/2005 kebijakan perberasan di Indonesia terbagi menjadi kebijakan produksi, kebijakan harga, kebijakan distribusi, dan kebijakan impor.

\subsection{Kebijakan Impor}

Kebijakan impor bertujuan untuk menekan jumlah dan mengurangi tingkat ketergantungan impor beras Indonesia. Kebijakan impor diimplementasikan melalui dua instrumen pokok yaitu hambatan tarif dan kuota tarif. Tahun 2000, pemerintah mengeluarkan kebijakan protektif dengan menetapkan tarif impor spesifik sebesar Rp 430 per $\mathrm{kg}$ (setara dengan ad valorem 30 persen). Kemudian nilai tarif tersebut dikoreksi kembali pada akhir tahun 2004 menjadi sebesar Rp 450 per kg yang berlaku pada awal tahun 2005.

Tahun 2004 pemerintah mengeluarkan ketentuan impor beras dalam SK Menperindag No.9/MPP/Kep/1/2004. SK ini menyangkut beberapa ketentuan penting adalah (1) bahwa impor beras hanya dapat dilakukan oleh importir yang telah mendapat pengakuan sebagai Importir Produsen Beras (IP) dan importir yang telah mendapat penunjukan sebagai Importir Terdaftar Beras (IT Beras) (2) pelarangan impor selama 1 bulan sebelum panen raya, selama panen raya, dan dua bulan setelah panen raya (sekitar bulan Januari-Juni) (3) pelaksanaan importisasi beras oleh IT beras hanya dapat dibongkar di pelabuhan yang tujuan sesuai dengan persetujuan impor yang diberikan oleh direktorat Jenderal Perdagangan Luar Negeri dan (4) beras yang diimpor oleh IP beras hanya boleh digunakan sebagai bahan baku untuk 
proses industri yang dimilikinya dan dilarang diperjual belikan.

\subsection{Perdagangan Internasional}

Indonesia termasuk negara berkembang yang berani dalam mengarahkan kebijakan perdagangan sesuai dengan tuntutan mekanisme pasar. Indonesia terikat untuk mematuhi ketentuan-ketentuan perdagangan internasional yang telah disepakati dalam perundingan General Agreement on Tariffs and trade (GATT) dan World Trade Organization (WTO). Ketentuanketentuan tersebut memberikan pengaruh terhadap sistem dan pranata hukum nasional di sektor perdagangan. Masuknya Indonesia sebagai anggota perdagangan dunia melalui ratifikasi terhadap Undang-Undang No.7 Tahun 1994 tentang pengesahan Agreement on Establishing WTO. Indonesia wajib mematuhi semua perjanjian yang ada di dalamnya termasuk perjanjian pertanian (Agreement on Agriculture/AOA).

Perjanjian ini bertujuan untuk melancarkan liberalisasi perdagangan dunia termasuk produk pertanian. Perjanjian ini terdapat tiga pilar utama yaitu: (1) akses pasar (MarketAccess) (2) subsidi domestik (Domestic Support) (3) subsidi export (export Subsidies).
Keikutsertaannya membawa konsekuensi baik eksternal maupun internal. Konsekuensi eksternal, Indonesia harus mematuhi seluruh hasil kesepakatan WTO. Konsekuensi internal Indonesia harus melakukan harmonisasi peraturan perundang-undangan nasional dengan ketentuan hasil kesepakatan WTO. Keikutsertaan Indonesia dalam perjanjian perdagangan internasional baik pada global (GATT-WTO) maupun regional (Asean Free Trade Area, Asia Pacific Economic Cooperation, danChina-Asean Free Trade Area) diharapkan dapat meningkatkan pertumbuhan ekonomi.

\subsection{Hipotesis}

Berdasarkan latar belakang permasalahan tersebut di atas maka permasalahan dalam penelitian ini sebagai berikut :

1. Bahwa terdapat perkembangan jumlah penduduk, produksi padi, harga beras lokal, harga jagung dan harga ubi kayu serta volume beras impor di Jawa Timur.

2. Bahwa jumlah penduduk, produksi padi, harga beras lokal, harga jagung dan harga ubi kayu berpengaruh terhadap volume beras impor di Jawa Timur. 
3. Diantara variabel jumlah penduduk, produksi padi, harga jagung dan harga ubi kayu, Jumlah Penduduk yang mempunyai pengaruh paling dominan terhadap jumlah permintaan beras impor di Jawa Timur.

\section{METODOLOGI PENELITIAN}

\subsection{Lokasi Penelitian}

Lokasi penelitian atau wilayah yang diamati dalam penelitian ini adalah Provinsi Jawa Timur. Dipilihnya Provinsi Jawa Timur sebagai lokasi penelitian karena Provinsi Jawa Timur merupakan salah satu pemasok kebutuhan beras Nasional.

\subsection{Populasi}

Populasi adalah keseluruhan obyek yang diamati. Yang menjadi populasi dalam penelitian ini adalah aktivitas perberasan yang dilakukan oleh pihak pemerintah Provinsi Jawa Timur selama kurun waktu 15 tahun terakhir.

\subsection{Sampel}

Sampel penelitian menggunakan tehnik probabilitas dengan metode sensus, yaitu tehnik untuk penentukan sampel dimana seluruh anggota populasi dijadikan sebagai sampel, sehingga sampel dalam penelitian ini adalah aktivitas perberasan yang dilakukan oleh pihak pemerintah Provinsi Jawa Timur selama kurun waktu 15 tahun terakhir.

\subsection{Teknik Analisis Data}

1) Uji Normalitas

Uji normalitas digunakan untuk mengetahui apakah suatu data mengikuti sebaran normal atau tidak. Untuk mengetahui apakah data tersebut mengikuti sebaran normal atau tidak dapat dilakukan dengan berbagai metode diantaranya metode Kolmogorov Smirnov atau metode Shapiro Wilk (Sumarsono, 2002:40). Nilai signifikansi atau nilai probabilitas $<0,05$ maka distribusi adalah tidak normal (simetris). Dan nilai signifikansi atau nilai probabilitas > 0,05 maka distribusi adalah normal (simetris).

2) Uji Asumsi Klasik

- Multikolinieritas

Menurut Ghozali (2006: 91) deteksi tidak adanya Multikolinieritas, yaitu mempunyai nilai VIF di bawah angka 10 dan mempunyai angka toleransi di bawah angka 10. Berdasarkan hasil pengujian dapat diketahui bahwa nilai VIF seluruh variabel bebas dalam penelitian ini di bawah angka 10, artinya 
seluruh variabel bebas pada penelitian ini tidak terjadi Multikolinieritas.

- Uji Heteroskedastisitas

Uji heteroskedastisitas bertujuan menguji apakah dalam model regresi terjadi ketidaksamaan variansi dari residual satu pengamatan ke pengamatan yang lain. Jika variansi dari residual satu pengamatan ke pengamatan lain tetap, maka disebut homoskedastisitas dan jika berbeda disebut heteroskedastisitas. Tingkat signifikan koefisien Rank Spearman untuk semua variabel bebas terhadap residual adalah lebih besar dari 0,05 yang berarti pada model regresi ini tidak terjadi heteroskedastisitas.

- Autokorelasi

Autokorelasi bertujuan menguji apakah dalam suatu model regresi linier ada korelasi antara kesalahan pengganggu pada t-1 (sebelumnya). Jika terjadi korelasi, maka dinamakan ada problem autokorelasi. Autokorelasi muncul karena observasi yang berurutan sepanjang waktu berkaitan satu sama lainnya Ghozali (2006: 91).

3) Analisis Regresi Linier Berganda

Untuk memudahkan dalam menjawab permasalahan dalam penelitian ini yaitu mengenai pengaruh variabel bebas terhadap variabel terikat, maka teknik analisis yang digunakan adalah persamaan regresi linier berganda sesuai dengan tujuan yang akan diteliti sebagai berikut :

$$
\begin{aligned}
Y= & \beta o+\beta_{1} X_{1}+\beta_{2} X_{2}+\beta_{3} X_{3}+\beta_{4} X_{4} \\
& +\beta_{5} X_{5}+e
\end{aligned}
$$

Dimana :

Y :Jumlah Permintaan Beras Impor $(\mathrm{Kg})$

$\mathrm{X}_{1}$ : Jumlah Penduduk (Jiwa)

$\mathrm{X}_{2}$ : Produksi Beras $(\mathrm{Kg})$

$\mathrm{X}_{3}$ : Harga Beras Lokal (Rupiah)

$\mathrm{X}_{4}$ : Harga Jagung (Rupiah)

$\mathrm{X}_{5}$ : Harga Ubi Kayu (Rupiah)

$\beta_{0}$ : Konstanta

$\beta_{1 . .} \beta_{7}:$ Koefisien regresi variabel

e : Standar Error

4) Uji Hipotesis

\section{- Uji F}

Menguji kesesuaian model regresi bahwa variabel $\left(X_{1}, X_{2}, X_{3}\right.$ dan $\left.X_{5}\right)$ berpengaruh terhadap $\mathrm{Y}$ dengan prosedur sebagai berikut :

1. Ho : $\beta_{1}=\beta_{2}=\beta_{3}=\beta_{5}=0$ (tidak ada pengaruh yang nyata antara variabel terikat dengan variabel bebas secara simultan).

Ho : $\beta_{1} \neq \beta_{2} \neq \beta_{3} \neq \beta_{5} \neq 0$ (ada pengaruh yang nyata antara variabel terikat dengan variabel bebas secara simultan)

2. Dalam penelitian digunakan tingkat signifikasi 0,05 
3. Dengan F hitung sebesar :

$$
F_{h i t}=\frac{R^{2} /(k-1)}{\left(1-R^{2}\right) /(n-k)}
$$

Keterangan :

$\mathrm{F}_{\text {hit }} \quad=$ hasil $\mathrm{F}$ hitung

$\mathrm{n} \quad$ = banyaknya sampel

$\mathrm{R}^{2}=$ koefisien determinasi

$\mathrm{k}=$ jumlah variabel

4. Dari uraian di atas, maka kriteria penujian hipotesis statistik sebagai berikut:

Ho diterima jika $F_{\text {hitung }} \leq \mathrm{F}_{\text {tabel, }}$, berarti tidak ada pengaruh secara simultan

Ho ditolak jika $F_{\text {hitung }}>F_{\text {tabel }}$, berarti ada pengaruh secara simultan

\section{- Uji t}

Pengujian hipotesis penelitian pengaruh variabel $\left(\mathrm{X}_{1}, \mathrm{X}_{2}, \mathrm{X}_{3}\right.$ dan $\left.\mathrm{X}_{5}\right)$ terhadap $\mathrm{Y}$ digunakan uji $\mathrm{t}$ dengan prosedur sebagai berikut :

1. Ho : $\mathrm{b}_{1}=0$ (tidak ada pengaruh yang nyata antara variabel terikat dengan variabel bebas secara parsial)

Ho : $b_{1} \neq 0$ (ada pengaruh yang nyata antara variabel terikat dengan variabel bebas secara parsial)

2. Dalam penelitian ini digunakan tingkat signifikan 0,05

3. Dengan nilai t hitung :

$$
t_{h i t}=\frac{b_{j}}{S e\left(b_{j}\right)}
$$

Keterangan :

$\mathrm{t}_{\text {hit }}=\mathrm{t}$ hasil perhitungan

$b_{j}=$ koefisien regresi

$\operatorname{Se}\left(b_{\mathrm{j}}\right) \quad=$ Simpangan baku untuk masing-masing koefisien regresi

4. Kriteria pengujian sebagai berikut :

Ho diterima jika $-\mathrm{t}_{\text {tabel }} \leq \mathrm{t}_{\text {hitung }} \leq \mathrm{t}$ tabel

Ho ditolak jika $\mathrm{t}_{\text {hitung }}<-\mathrm{t}_{\text {tabel }}$ atau $\mathrm{t}$ hitung $>t_{\text {tabel }}$

\subsection{Definisi Operasional Variabel}

1) Jumlah Penduduk

Jumlah penduduk merupakan banyaknya orang berdomisili dan tercatat sebagai warga Jawa Timur. Data pada variabel ini menggunakan skala rasio dan informasi jumlah penduduk dapat diperoleh di BPS Jawa Timur dengan satuan Jiwa.

2) Produksi padi

Produksi padi merupakan kemampuan dari Provinsi Jawa Timur dalam menghasilkan padi tiap tahunnya. Data pada variabel ini menggunakan skala rasio dapat diperoleh di BPS Jawa Timur dengan satuan Ton. 


\section{3) Harga Beras Lokal}

Harga beras adalah harga komoditi beras yang sudah ditambah dengan biaya transportasi dalam pendistribusiannya (harga pasar) dan telah ditetapkan pada wilayah tersebut yang dapat dipeorleh di BPS Jawa Timur. Satuan dalam variabel ini adalah rupiah/kilogram

4) Harga Jagung

Harga jagung adalah harga komoditi jagung yang sudah ditambah dengan biaya transportasi dalam pendistribusiannya (harga pasar) dan telah ditetapkan pada wilayah tersebut yang dapat dipeorleh di BPS Jawa Timur. Satuan dalam variabel ini adalah rupiah/kilogram

\section{5) Harga Ubi Kayu}

Harga ubi kayu adalah harga komoditi ubi kayu yang sudah ditambah dengan biaya transportasi dalam pendistribusiannya (harga pasar) dan telah ditetapkan pada wilayah tersebut yang dapat dipeorleh di BPS Jawa Timur. Satuan dalam variabel ini adalah rupiah/kilogram

6) Volume Beras Impor

Volume Beras Impor merupakan kapasitas atau jumlah beras impor yang masuk kedalam Provinsi Jawa Timur melalui pelabuhan-pelabuhan atau terminal impor di Provinsi Jawa Timur yang dapat dipeorleh di BPS Jawa Timur. Satuan dalam variabel ini adalah $\mathrm{Kg}$.

\subsection{Pengukuran Variabel}

Variabel dalam penelitian ini diukur dengan menggunakan skala rasio. Pengertian skal rasio adalah skala interval yang memiliki nilai dasar (based value) yang tidak dapat diubah dengan satuan yang disesuaikan dengan variabel yang digunakan

\section{PEMBAHASAN}

\subsection{Hasil Uji Normalitas}

Tabel 1. Uji Normalitas

Tests of Nor mality
\begin{tabular}{|l|r|r|r|}
\hline \multicolumn{1}{|c|}{ Kolmogorov-Smirnov ${ }^{\mathrm{a}}$} \\
\cline { 2 - 4 } & \multicolumn{1}{|c|}{ Statistic } & df & \multicolumn{1}{c|}{ Sig. } \\
\hline Jumlah Penduduk &, 195 & 15 &, 131 \\
Produksi Padi &, 204 & 15 &, 093 \\
Harga Beras Lokal &, 134 & 15 &, $200^{*}$ \\
Harga Jagung &, 211 & 15 &, 070 \\
Harga Ubi Kayu &, 137 & 15 &, $200^{*}$ \\
Volume Beras Impor &, 118 & 15 &, $200^{*}$ \\
\hline
\end{tabular}
*. This is a low er bound of the true significance.
a. Lilliefors Signific ance Correction

Berdasarkan Tabel 1 di atas dapat diketahui bahwa nilai statistik Kolmogorov-Smirnov yang diperoleh mempunyai taraf signifikan yang lebih besar dari 0,05. Hal ini membuktikan bahwa semua variabel yang diteliti berdistribusi normal. 


\subsection{Hasil Uji Asumsi Klasik}

a. Uji Multikolinearitas

Tabel 2. Uji Multikolinearias

\begin{tabular}{|c|c|c|c|}
\hline \multicolumn{4}{|c|}{ Coefficients } \\
\hline \multirow[b]{2}{*}{ Model } & & \multicolumn{2}{|c|}{ Collinearity Statistics } \\
\hline & & Tolerance & VIF \\
\hline 1 & Jumlah Penduduk &, 450 & 2,224 \\
\hline & Produksi Padi & ,844 & 1,185 \\
\hline & Harga Beras Lokal & 271 & 3,686 \\
\hline & Harga Jagung & ,152 & 6,563 \\
\hline & Harga Ubi Kayu &, 159 & 6,289 \\
\hline
\end{tabular}

a. Dependent Variable: Volume Beras Impor

Berdasarkan hasil pengujian dapat diketahui bahwa nilai VIF seluruh variabel bebas dalam penelitian ini di bawah angka 10, artinya seluruh variabel bebas pada penelitian ini tidak terjadi Multikolinieritas.

\section{b. Uji Heteroskedastisitas}

Tabel 3 menunjukkan bahwa taraf signifikansi untuk masing-masing variabel bebasnya di atas 0,05 dapat diputuskan tidak terjadi heteroskedastisitas.

Tabel 3. Uji Heteroskedastisitas

\begin{tabular}{|c|c|c|c|c|c|c|c|c|}
\hline \multicolumn{9}{|c|}{ Correlations } \\
\hline & & & $\begin{array}{l}\text { Unstandardiz } \\
\text { ed Residual }\end{array}$ & $\begin{array}{c}\text { Jumlah } \\
\text { Penduduk }\end{array}$ & Produksi Padi & $\begin{array}{c}\text { Harga } \\
\text { Beras Lokal }\end{array}$ & Harga Jagung & $\begin{array}{c}\text { Harga } \\
\text { Ubi Kayu } \\
\end{array}$ \\
\hline \multirow[t]{18}{*}{ Spearman's rho } & \multirow[t]{3}{*}{ Unstandardized Residual } & \multirow{3}{*}{$\begin{array}{l}\text { Correlation Coefficient } \\
\text { Sig. (2-tailed) } \\
\mathrm{N}\end{array}$} & \multirow[t]{2}{*}{1,000} & ,043 &,- 039 &,- 182 &,- 039 &,- 089 \\
\hline & & & & ,879 & ,889 &, 516 & ,889 &, 752 \\
\hline & & & 15 & 15 & 15 & 15 & 15 & 15 \\
\hline & \multirow[t]{3}{*}{ Jumlah Penduduk } & Correlation Coefficient & , 043 & 1,000 & , 021 & ,746** &, $721^{* \star}$ & ,746** \\
\hline & & Sig. (2-tailed) &, 879 & . & ,940 &, 001 &, 002 &, 001 \\
\hline & & $\mathrm{N}$ & 15 & 15 & 15 & 15 & 15 & 15 \\
\hline & \multirow[t]{3}{*}{ Produksi Padi } & Correlation Coefficient &,- 039 & ,021 & 1,000 &,- 189 &,- 346 &,- 350 \\
\hline & & Sig. (2-tailed) &, 889 & 940 & . & ,499 & ,206 & ,201 \\
\hline & & $\mathrm{N}$ & 15 & 15 & 15 & 15 & 15 & 15 \\
\hline & \multirow[t]{3}{*}{ Harga Beras Lokal } & Correlation Coefficient &,- 182 &, $746^{* \star}$ &,- 189 & 1,000 &, $896^{* \star}$ & ,871** \\
\hline & & Sig. (2-tailed) &, 516 & 001 & ,499 & . &, 000 &, 000 \\
\hline & & $\mathrm{N}$ & 15 & 15 & 15 & 15 & 15 & 15 \\
\hline & \multirow[t]{3}{*}{ Harga Jagung } & Correlation Coefficient &,- 039 & ,721** &,- 346 & ,896** & 1,000 & $929 * *$ \\
\hline & & Sig. (2-tailed) & ,889 & ,002 & ,206 &, 000 & 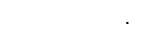 &, 000 \\
\hline & & $\mathrm{N}$ & 15 & 15 & 15 & 15 & 15 & 15 \\
\hline & \multirow[t]{3}{*}{ Harga Ubi Kayu } & Correlation Coefficient &,- 089 &, $746^{* *}$ &,- 350 & ,871** & ,929** & 1,000 \\
\hline & & Sig. (2-tailed) & ,752 & 001 & ,201 &, 000 &, 000 & . \\
\hline & & $\mathrm{N}$ & 15 & 15 & 15 & 15 & 15 & 15 \\
\hline
\end{tabular}

\section{c. Uji Autokorelasi}

Dalam penelitian ini, besarnya Durbin Watson setelah dianalisis adalah 2,448 . Untuk mengetahui adanya gejala autokorelasi maka perlu dilihat tabel Durbin Watson dengan jumlah variabel bebas $\mathrm{K}=5$ sedangkan jumlah pengamatan 15 maka diperoleh $\mathrm{dl}=$ 0,560 dan $d u=2,210$. Selanjutnya nilai tersebut diplotkan ke kurva Durbin Watson dibawah ini: 


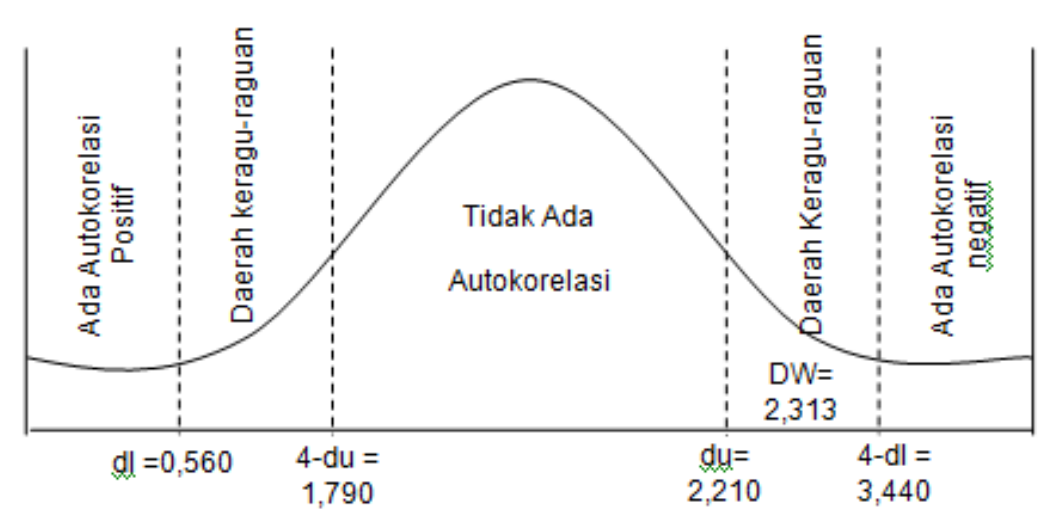

Gambar 1. Kurva Durbin Watson

Berdasarkan gambar diatas dapat diketahui bahwa distribusi daerah penentuan keputusan dimulai dari 0 (nol) sampai 4 (empat). Dan dapat disimpulkan karena nilai dari analisis sebesar 2,313 berada pada daerah keragu-raguan, namun bukan pada daerah terdapat autokorelasi positif maupun negatif sehingga dapat diputuskan bahwa seluruh variabel yang digunakan dalam penelitian ini telah terbebas dari penyimpangan autokorelasi.

\subsection{Hasil Uji Regresi Linear Berganda}

Tabel 4. Uji Regresi Linear Berganda

\begin{tabular}{|c|c|c|c|c|c|c|c|c|c|}
\hline \multicolumn{10}{|c|}{ Coefficients } \\
\hline \multirow[b]{2}{*}{ Model } & & \multicolumn{2}{|c|}{$\begin{array}{l}\text { Unstandardized } \\
\text { Coefficients }\end{array}$} & \multirow{2}{*}{$\begin{array}{c}\begin{array}{c}\text { Standardized } \\
\text { Coefficients }\end{array} \\
\text { Beta }\end{array}$} & \multirow[b]{2}{*}{$t$} & \multirow[b]{2}{*}{ Sig. } & \multicolumn{3}{|c|}{ Correlations } \\
\hline & & B & Std. Error & & & & Zero-order & Partial & Part \\
\hline 1 & (Constant) & 4077695 & $1 \mathrm{E}+007$ & & ,396 & ,701 & & & \\
\hline & Jumlah Penduduk &, 095 & ,310 & ,031 & ,306 & ,766 & ,632 & 102 & ,021 \\
\hline & Produksi Padi &,- 637 & ,277 &,- 170 & $-2,303$ & ,047 &,- 303 &,- 609 &,- 156 \\
\hline & Harga Beras Lokal & 2614,241 & 460,289 & ,739 & 5,680 & ,000 & ,948 & ,884 & ,385 \\
\hline & Harga Jagung & $-321,338$ & 952,014 &,- 059 &,- 338 & ,743 & ,858 &,- 112 &,- 023 \\
\hline & Harga Ubi Kayu & 1710,997 & 1086,441 & ,268 & 1,575 &, 150 & 886 &, 465 &, 107 \\
\hline
\end{tabular}

a. Dependent Variable: Volume Beras Impor

$$
\begin{aligned}
& \mathbf{Y}=\mathbf{4 0 7 7 6 9 5}+\mathbf{0 , 0 9 5} \mathbf{X}_{1}-\mathbf{0 , 6 3 7} \mathbf{X}_{2}+\text { Dari persamaan tersebut dapat dijelaskan } \\
& \text { 2614,241 } X_{3}-\mathbf{3 2 1 , 3 3 8} \mathbf{X}_{4}+\quad \text { sebagai berikut: } \\
& 1710,997 X_{5}
\end{aligned}
$$




\section{Konstanta $\left(\boldsymbol{\beta}_{0}\right)$}

Nilai konstanta sebesar 4077695 menunjukkan apabila variabel jumlah penduduk $\left(\mathrm{X}_{1}\right)$, produksi padi $\left(\mathrm{X}_{2}\right)$, harga beras lokal $\left(\mathrm{X}_{3}\right)$, harga jagung $\left(\mathrm{X}_{4}\right)$ dan harga ibu kayu $\left(\mathrm{X}_{5}\right)$ sebesar nol atau konstan, maka besarnya nilai volume beras impor adalah sebesar 4077695 .

\section{Jumlah Penduduk $\left(\mathbf{X}_{1}\right)$}

Koefisien regresi untuk variabel jumlah penduduk $\left(\mathrm{X}_{1}\right)$ sebesar 0,095. Tanda positif menunjukkan terjadinya perubahan yang searah dari variabel jumlah penduduk $\left(\mathrm{X}_{1}\right)$ terhadap variabel volume beras impor (Y), yang artinya apabila variabel jumlah penduduk $\left(\mathrm{X}_{1}\right)$ mengalami peningkatan sebesar 1 jiwa maka variabel nilai volume beras impor (Y) akan meningkat sebesar 0,095, demikian sebaliknya apabila variabel jumlah penduduk $\left(\mathrm{X}_{1}\right)$ mengalami penurunan sebesar 1 jiwa maka variabel nilai volume beras impor (Y) akan menurun sebesar 0,095 dengan asumsi bahwa variabel-variabel yang lain adalah konstan.

\section{Produksi Padi $\left(\mathbf{X}_{2}\right)$}

Koefisien regresi untuk variabel produksi padi $\left(\mathrm{X}_{2}\right)$ sebesar $-0,637$. Tanda negatif menunjukkan terjadinya perubahan yang berlawanan arah dari variabel produksi padi $\left(\mathrm{X}_{2}\right)$ terhadap variabel volume beras impor (Y), yang artinya apabila variabel produksi padi $\left(\mathrm{X}_{2}\right)$ mengalami peningkatan sebesar 1 ton maka volume beras impor (Y) akan menurun sebesar 0,637 demikian sebaliknya apabila variabel produksi padi $\left(\mathrm{X}_{2}\right)$ mengalami penurunan sebesar 1 ton maka variabel volume beras impor (Y) akan meningkat sebesar 0,637 dengan asumsi bahwa variabel-variabel yang lain adalah konstan.

\section{Beras Lokal $\left(\mathbf{X}_{3}\right)$}

Koefisien regresi untuk variabel harga beras lokal $\left(\mathrm{X}_{3}\right)$ sebesar 2614,241. Tanda positif menunjukkan terjadinya perubahan yang searah dari variabel harga beras lokal $\left(\mathrm{X}_{3}\right)$ terhadap variabel volume beras impor (Y), yang artinya apabila variabel harga beras lokal $\left(\mathrm{X}_{3}\right)$ mengalami peningkatan sebesar 1 rupiah maka variabel volume beras impor (Y) akan meningkat sebesar 2614,241 demikian sebaliknya apabila variabel harga beras lokal $\left(\mathrm{X}_{3}\right)$ mengalami penurunan sebesar 1 rupiah maka variabel volume beras impor (Y) akan menurun sebesar 2614,241 dengan asumsi bahwa variabel-variabel yang lain adalah konstan. 


\section{Harga Jagung $\left(\mathbf{X}_{4}\right)$}

Koefisien regresi untuk variabel harga jagung $\left(\mathrm{X}_{4}\right)$ sebesar $-321,338$. Tanda negatif menunjukkan terjadinya perubahan yang berlawanan arah dari variabel harga jagung $\left(\mathrm{X}_{4}\right)$ terhadap variabel volume beras impor $(\mathrm{Y})$, yang artinya apabila variabel harga jagung $\left(\mathrm{X}_{4}\right)$ mengalami peningkatan sebesar 1 rupiah maka variabel volume beras impor (Y) akan menurun sebesar 321,338, demikian sebaliknya apabila variabel harga jagung $\left(\mathrm{X}_{4}\right)$ mengalami penurunan sebesar 1 rupiah maka volume beras impor (Y) akan meningkat sebesar 321,338 dengan asumsi bahwa variabel-variabel yang lain adalah konstan.

\section{Harga Ubi Kayu ( $\left.\mathbf{X}_{5}\right)$}

Koefisien regresi untuk variabel harga ubi kayu $\left(\mathrm{X}_{5}\right)$ sebesar 1710,997. Tanda positif menunjukkan terjadinya perubahan yang searah dari variabel harga ubi kayu $\left(\mathrm{X}_{5}\right)$ terhadap variabel volume beras impor (Y), yang artinya apabila variabel harga ubi kayu $\left(\mathrm{X}_{5}\right)$ mengalami peningkatan sebesar 1 rupiah maka variabel volume beras impor $(\mathrm{Y})$ akan meningkat sebesar 1710,997, demikian sebaliknya apabila variabel harga ubi kayu $\left(\mathrm{X}_{5}\right)$ mengalami penurunan sebesar 1 rupiah maka volume beras impor (Y) akan menurun sebesar 1710,997 dengan asumsi bahwa variabel-variabel yang lain adalah konstan.

\subsection{Hasil Uji F}

Tabel 5. Uji F

\begin{tabular}{|c|c|c|c|c|c|c|}
\hline \multicolumn{7}{|c|}{ ANOV A } \\
\hline & & Sum of Squares & df & Mean Square & $\mathrm{F}$ & Sig. \\
\hline \multirow[t]{3}{*}{1} & Regression & 313433767904711 & 5 & 62686753580942 & 41,753 &, $000^{a}$ \\
\hline & Residual & 13512280095066,1 & 9 & 1501364455007,3 & & \\
\hline & Total & 326946047999777 & 14 & & & \\
\hline
\end{tabular}

Berdasarkan hasil pengujian diketahui bahwa nilai $F_{\text {hitung }}$ yang diperoleh adalah sebesar 41,753 dengan taraf signifikan sebesar 0,000. Karena taraf signifikansi yang lebih kecil dari 0,05, maka model regresi yang dihasilkan dalam penelitian ini cocok digunakan dalam untuk menguji hipotesis yang diajukan. 
Tabel 6. Model Summary

Model Summary

\begin{tabular}{|l|r|r|r|r|}
\hline & & & & \\
Model & $\mathrm{R}$ & $\mathrm{R}$ Square & $\begin{array}{c}\text { Adjusted } \\
\text { R Square }\end{array}$ & $\begin{array}{c}\text { Std. Error of } \\
\text { the Estimate }\end{array}$ \\
\hline 1 &, $979^{\mathrm{a}}$ &, 959 &, 936 & 1225301,781 \\
\hline
\end{tabular}

a. Predictors: (Constant), Harga Ubi Kayu, Produksi Padi, Jumlah Penduduk, Harga Beras Lokal, Harga Jagung

b. Dependent Variable: Volume Beras Impor

Berdasarkan hasil pengujian diketahui bahwa besarnya nilai korelasi $\mathrm{R}$ variabel Jumlah Penduduk $\left(\mathrm{X}_{1}\right)$, Produksi Padi $\left(\mathrm{X}_{2}\right)$, Harga Beras Lokal $\left(\mathrm{X}_{3}\right)$, Harga jagung $\left(\mathrm{X}_{4}\right)$ dan Harga Ubi Kayu $\left(\mathrm{X}_{5}\right)$ dengan Volume Beras Impor (Y), adalah R sebesar 0,979 atau 97,9\%. Hal tersebut menunjukkan adanya korelasi yang kuat antara variabel Jumlah Penduduk $\left(\mathrm{X}_{1}\right)$, Produksi Padi $\left(\mathrm{X}_{2}\right)$, Harga Beras Lokal $\left(\mathrm{X}_{3}\right)$, Harga jagung $\left(\mathrm{X}_{4}\right)$ dan Harga Ubi Kayu $\left(\mathrm{X}_{5}\right)$ dengan volume beras impor (Y), sedangkan besarnya nilai koefisien determinasi $\left(\mathrm{R}^{2}\right)$ adalah 0,959 yang berarti bahwa variabel Jumlah Penduduk $\left(\mathrm{X}_{1}\right)$, Produksi Padi $\left(\mathrm{X}_{2}\right)$, Harga Beras Lokal $\left(\mathrm{X}_{3}\right)$, Harga jagung $\left(\mathrm{X}_{4}\right)$ dan Harga Ubi Kayu $\left(\mathrm{X}_{5}\right)$ Terhadap Volume Beras Impor (Y) mampu menjelaskan perubahan pada variabel Volume Beras Impor (Y) sebesar 95,9\% dan sisanya sebesar $4,1 \%$ dijelaskan oleh variabel lain yang tidak dibahas dalam masalah penelitian ini.

\subsection{Hasil Uji t}

Tabel 7. Uji t

Coefficients

\begin{tabular}{|c|c|c|c|c|c|c|c|c|c|}
\hline \multirow{2}{*}{\multicolumn{2}{|c|}{ Model }} & \multicolumn{2}{|c|}{$\begin{array}{l}\text { Unstandardized } \\
\text { Coefficients }\end{array}$} & \multirow{2}{*}{$\begin{array}{c}\begin{array}{c}\text { Standardized } \\
\text { Coefficients }\end{array} \\
\text { Beta }\end{array}$} & \multirow[b]{2}{*}{$t$} & \multirow[b]{2}{*}{ Sig. } & \multicolumn{3}{|c|}{ Correlations } \\
\hline & & B & Std. Error & & & & Zero-order & Partial & Part \\
\hline \multirow[t]{6}{*}{1} & (Cons tant) & 4077695 & 10287864,0 & &, 396 & ,701 & & & \\
\hline & Jumlah Penduduk & ,095 & ,310 & ,031 & ,306 & ,766 & ,632 & 102 & ,021 \\
\hline & Produksi Padi &,- 637 & ,277 &,- 170 & $-2,303$ &, 047 &,- 303 &,- 609 &,- 156 \\
\hline & Harga Beras Lokal & 2614,241 & 460,289 &, 739 & 5,680 &, 000 & ,948 & ,884 & ,385 \\
\hline & Harga Jagung & $-321,338$ & 952,014 &,- 059 &,- 338 & ,743 & ,858 &,- 112 &,- 023 \\
\hline & Harga Ubi Kayu & 1710,997 & 1086,441 & ,268 & 1,575 & 150 & ,886 & ,465 & , 107 \\
\hline
\end{tabular}

a. Dependent Variable: Volume Beras Impor 
Sedangkan untuk pengaruh nyata tidaknya masing-masing variabel dapat dijelaskan sebagai berikut :

1. Pengaruh Variabel Jumlah

Penduduk $\left(\mathrm{X}_{1}\right)$ Terhadap Volume

Beras Impor (Y).

Nilai koefisien korelasi (r) parsial variabel Jumlah Penduduk $\left(\mathrm{X}_{1}\right)$ dengan Volume Beras Impor (Y) adalah sebesar 0,102 . Sedangkan nilai koefisien determinasi atau pengaruh $\left(\mathrm{r}^{2}\right)$ parsial variabel jumlah penduduk $\left(\mathrm{X}_{1}\right)$ terhadap Volume Beras Impor (Y) adalah sebesar $(0,102)^{2}=0,010$ atau $1 \%$. Jadi pengaruh yang telah diberikan oleh Variabel jumlah penduduk $\left(\mathrm{X}_{1}\right)$ terhadap Volume Beras Impor (Y) sebesar 1\%. Sedangkan nilai $t_{\text {hitung }}$ yang diperoleh adalah 0,306 dengan taraf signifikan sebesar 0,766. Karena taraf signifikan yang diperoleh lebih besar dari 0,05, maka tidak secara nyata jumlah penduduk $\left(\mathrm{X}_{1}\right)$ berpengaruh terhadap Volume Beras Impor (Y).

2. Pengaruh Variabel Produksi padi $\left(\mathrm{X}_{2}\right)$ Terhadap Volume Beras Impor (Y)

Nilai koefisien korelasi (r) parsial variabel Produksi padi $\left(\mathrm{X}_{2}\right)$ dengan Volume Beras Impor (Y) adalah sebesar $-0,609$. Sedangkan nilai koefisien determinasi atau pengaruh $\left(\mathrm{r}^{2}\right)$ parsial variabel Produksi padi $\left(\mathrm{X}_{2}\right)$ terhadap Volume Beras Impor (Y) adalah sebesar $(-0,609)^{2}=0,370$ atau $37 \%$. Jadi pengaruh yang telah diberikan oleh Variabel Produksi padi $\left(\mathrm{X}_{2}\right)$ terhadap Volume Beras Impor (Y) sebesar 37\%. Sedangkan nilai $t_{\text {hitung }}$ yang diperoleh adalah -2,303 dengan taraf signifikan sebesar 0,047. Karena taraf signifikan yang diperoleh lebih besar dari 0,05, maka secara nyata variabel Produksi padi $\left(\mathrm{X}_{2}\right)$ berpengaruh terhadap Volume Beras Impor (Y).

3. Pengaruh Variabel Harga Beras Lokal $\left(\mathrm{X}_{3}\right)$ Terhadap Volume Beras Impor (Y)

Nilai koefisien korelasi (r) parsial variabel Harga Beras Lokal $\left(\mathrm{X}_{3}\right)$ dengan Volume Beras Impor (Y) adalah sebesar 0,884. Sedangkan nilai koefisien determinasi atau pengaruh $\left(\mathrm{r}^{2}\right)$ parsial variabel Harga Beras Lokal $\left(\mathrm{X}_{3}\right)$ terhadap Volume Beras Impor (Y) adalah sebesar $(0,884)^{2}=0,781$ atau $78,1 \%$. Jadi pengaruh yang telah diberikan oleh Variabel Harga Beras Lokal $\left(\mathrm{X}_{3}\right)$ terhadap Volume Beras Impor (Y) sebesar 78,1\%. Sedangkan nilai $t_{\text {hitung }}$ yang diperoleh adalah 5,680 dengan taraf signifikan sebesar 0,000 . Karena taraf signifikan yang diperoleh lebih kecil dari 0,05, maka secara nyata 
variabel Harga Beras Lokal $\left(\mathrm{X}_{3}\right)$ berpengaruh terhadap Volume Beras Impor (Y).

4. Pengaruh Variabel Harga Jagung $\left(\mathrm{X}_{4}\right)$

Terhadap Volume Beras Impor (Y)

Nilai koefisien korelasi (r) parsial variabel Harga Jagung $\left(\mathrm{X}_{4}\right)$ dengan Volume Beras Impor (Y) adalah sebesar -0,112. Sedangkan nilai koefisien determinasi atau pengaruh $\left(\mathrm{r}^{2}\right)$ parsial variabel Harga Jagung $\left(\mathrm{X}_{4}\right)$ terhadap Volume Beras Impor (Y) adalah sebesar $(-0,112)^{2}=0,013$ atau $1,3 \%$. Jadi pengaruh yang telah diberikan oleh Variabel Harga Jagung $\left(\mathrm{X}_{4}\right)$ terhadap Volume Beras Impor (Y) sebesar 1,3\%. Sedangkan nilai $t_{\text {hitung }}$ yang diperoleh adalah -0,338 dengan taraf signifikan sebesar 0,743. Karena taraf signifikan yang diperoleh lebih besar dari 0,05, maka tidak secara nyata variabel Harga Jagung $\left(\mathrm{X}_{4}\right)$ berpengaruh terhadap Volume Beras Impor (Y).

5. Pengaruh Variabel Harga Ubi Kayu $\left(\mathrm{X}_{5}\right)$ Terhadap Volume Beras Impor (Y)

Nilai koefisien korelasi (r) parsial variabel Harga Ubi Kayu ( $\left.\mathrm{X}_{5}\right)$ dengan Volume Beras Impor (Y) adalah sebesar 0,465. Sedangkan nilai koefisien determinasi atau pengaruh $\left(\mathrm{r}^{2}\right)$ parsial variabel Harga Ubi Kayu $\left(\mathrm{X}_{5}\right)$ terhadap
Volume Beras Impor (Y) adalah sebesar $(0,465)^{2}=0,220$ atau $22 \%$. Jadi pengaruh yang telah diberikan oleh Variabel Harga Ubi Kayu $\left(\mathrm{X}_{5}\right)$ terhadap Volume Beras Impor (Y) sebesar 22\%. Sedangkan nilai $t_{\text {hitung }}$ yang diperoleh adalah 1,575 dengan taraf signifikan sebesar 0,150. Karena taraf signifikan yang diperoleh lebih besar dari 0,05, maka tidak secara nyata variabel Harga Ubi Kayu $\left(\mathrm{X}_{5}\right)$ berpengaruh terhadap Volume Beras Impor (Y).

\subsection{Pengaruh Variabel Jumlah Penduduk $\left(\mathrm{X}_{1}\right)$ Terhadap Volume Beras Impor (Y)}

Hasil penelitian menunjukkan bahwa Jumlah Penduduk tidak berpengaruh signifikan terhadap Volume Beras Impor. Hasil ini didasarkan pada hasil pengujian uji t pada uji regresi dengan nilai signifikansi yang diperoleh sebesar 0,766 dimana nilai yang diperoleh tersebut lebih besar dari 0,05 dan bertanda positif. Hasil tersebut menunjukkan bahwa dengan bertambahnya penduduk maka akan memberikan peluang untuk bertambahnya volume beras impor yang masuk kedalam Provinsi Jawa Timur.

Tidak signifikannya pengaruh yang diberikan oleh jumlah penduduk 
terhadap volume beras impor dapat disebabkan karena meskipun jumlah penduduk di Provinsi Jawa Timur mengalami penambahan, namun apabila stok beras yang dimiliki oleh bulog masih memadai untuk menunjang kebutuhan masyarakat akan beras, maka volume beras impor yang masuk ke dalam Provinsi Jawa Timur akan mampu di tekan, akan tetapi disisi lain tidak dapat di pungkiri bahwa seiring dengan bertambahnya jumlah penduduk yang ada di provinsi Jawa timur jumlah punduduk yang kurang mampu pun mengalami peningkatan. Hal tersebutlah yang kemudian mendorong volume beras impor menguat kembali karena dibutuhkan untuk menjaga kestabilan kondisi perberasan di Jawa Timur dan agar dapat memberikan subsidi kepada penduduk yang kurang mampu.

Hasil penelitian ini sesuai dengan penelitian terdahulu yang dilakukan oleh Astuti (2007) yang menyatakan bahwa di Indonesia secara umum dan khususnya di jawa Jawa Timur terbukti masih terjadi aktivitas pengimporan beras meskipun tarif impor mengalami kenaikan, hal ini semakin membuktikan bahwa efisiensi produksi pangan di Indonesia masih rendah.

\subsection{Pengaruh Variabel Produksi padi $\left(\mathbf{X}_{2}\right)$ Terhadap Volume Beras Impor (Y)}

Hasil penelitian menunjukkan bahwa produksi padi berpengaruh signifikan terhadap Volume Beras Impor. Hasil ini didasarkan pada hasil pengujian uji t pada uji regresi dengan nilai signifikansi yang diperoleh sebesar 0,047 dimana nilai yang diperoleh tersebut lebih kecil dari 0,05 dan bertanda negatif. Hasil tersebut menunjukkan bahwa dengan bertambahnya produksi padi maka akan memperkcil peluang untuk bertambahnya volume beras impor yang masuk kedalam Provinsi Jawa Timur.

Kondisi tersebut dapat disebabkan karena dampak yang diberikan oleh produksi padi terhadap volume beras impor signifikan. Hal tersebut tergambar ketika produksi padi mengalami peningkatan atau dalam kondisi surplus maka pemerintah akan merasa aman dalam menjaga ketahanan pangan di Provinsi Jawa Timur, akan tetapi apabila produksi padi menglami minus, maka alternatif yang akan dilakukan oleh pemerintah untuk menjaga ketahanan pangan dan stabilitas kondisi perberasan di Jawa Timur yakni dengan menambah volume beras impor. 
Hasil penelitian ini sesuai teori yang dikemukakan oleh Tambunan (2008) yang menyatakan bahwa aktivitas impor beras sangat dipengaruhi oleh produksi padi, pemerintah seharusnya menerapkan kebijakan yang akan mendukung peningkatan produksi padi terutama dengan prioritas utama pemenuhan kebutuhan beras dari produksi dalam negeri. Selama ini, pemerintah/bulog lebih banyak mengandalkan pemenuhan stock berasnya dari impor, karena harga beras impor jauh lebih murah. Peningkatan produksi padi dan beras, akan meningkatkan penawaran beras nasional sehingga harga yang terjadi di pasar tidak terlalu tinggi dan semikian volume beras impor juga akan mengalami penurunan.

\subsection{Pengaruh Variabel Harga Beras} Lokal $\left(\mathbf{X}_{3}\right)$ Terhadap Volume Beras Impor (Y)

Hasil penelitian menunjukkan bahwa harga beras lokal berpengaruh signifikan terhadap Volume Beras Impor. Hasil ini didasarkan pada hasil pengujian uji t pada uji regresi dengan nilai signifikansi yang diperoleh sebesar 0,000 dimana nilai yang diperoleh tersebut lebih kecil dari 0,05 dan bertanda positif. Hasil tersebut menunjukkan bahwa dengan semakin tingginya harga jual beras lokal yang di tetapkan, akan semakin meningkatkan volume beras impor yang masuk ke Provinsi Jawa Timur.

Kondisi tersebut dapat disebabkan dengan semakin mahalnya harga pupuk dan bahan-bahan lainnya yang menunjang tanaman padi di Indonesia, maka akan mendorong peningkatan harga jual dari hasil produksi padi tersebut guna menyeimbangkan antara modal dengan keuntungan, hal ini tentunya akan menjadikan kompetitor dari luar negeri untuk memberikan penawaran beras dengan harga yang lebih murah. Oleh karena situasi dan kondisi ketahanan pangan yang mendesak jalan imporlah yang akhirnya akan ditempuh guna mengatasi kebutuhan pangan tersebut.

Hasil ini sesuai dengan penelitian yang dilakukan oleh Afrianto (2010) yang menyatakan bahwa Berkaitan dengan harga beras dalam negeri, diupayakan agar harga yang terjadi di pasar tidak terlalu tinggi dan juga tidak terlalu rendah. Harga beras yang tinggi akan memberatkan masyarakat miskin di perkotaan dan menyebabkan impor beras meningkat. Sementara harga beras yang 
terlalu rendah menyebabkan insentif petani untuk berproduksi menurun dan dalam jangka panjang akan berdampak kepada penurunan produksi beras.

\subsection{Pengaruh Variabel Harga Jagung $\left(\mathbf{X}_{4}\right)$ Terhadap Volume Beras Impor (Y)}

Hasil penelitian menunjukkan bahwa harga jagung tidak berpengaruh signifikan terhadap Volume Beras Impor. Hasil ini didasarkan pada hasil pengujian uji t pada uji regresi dengan nilai signifikansi yang diperoleh sebesar 0,743 dimana nilai yang diperoleh tersebut lebih besar dari 0,05 dan bertanda negatif. Hasil tersebut menunjukkan bahwa dengan semakin meningkatnya harga jagung di Provinsi Jawa Timur, maka cenderung akan menurunkan volume beras impor di provinsi Jawa Timur.

Kondisi tersebut dapat disebabkan karena dengan semakin meningkatnya harga jagung, maka petani akan semakin berusaha mengoptimalkan pertanian padi dengan harapan ketika panen akan mencapai harga yang meningkat pula, namun dengan adanya pemikiran yang sama dari sebagian besar petani di Provinsi Jawa Timur tersebut justru menyebabkan stok padi menjadi lebih banyak dan harganya pun cenderung menurun sehingga mampu menekan besarnya volume beras impor. Jagung yang merupakan barang subtitusi pengganti beras ini banyak dimanfaatkan sebagai makanan pokok oleh sebagian besar masyarakat di Madura. Hal ini dilakukan sebagai upaya untuk mengatasi masalah ketersediaan pangan masyarakat ketika harga beras mengalami lonjakan yang cukup tinggi yakni dengan diolah menjadi beras jagung.

Hasil penelitian ini sesuai dengan penelitian yang dikemukakan oleh Afrianto (2010) yang menyatakan bahwa Variabel harga jagung memiliki pengaruh negatif namun tidak signifikan terhadap ketahanan pangan di Jawa Tengah tahun 2005-2007.

\subsection{Pengaruh Variabel Harga Ubi Kayu $\left(\mathbf{X}_{5}\right)$ Terhadap Volume Beras Impor (Y)}

Hasil penelitian menunjukkan bahwa harga ubi kayu tidak berpengaruh signifikan terhadap Volume Beras Impor. Hasil ini didasarkan pada hasil pengujian uji t pada uji regresi dengan nilai signifikansi yang diperoleh sebesar 0,150 dimana nilai yang diperoleh tersebut lebih besar dari 0,05 dan 
bertanda positif. Hasil tersebut menunjukkan bahwa dengan semakin meningkatnya harga ubi kayu di Provinsi Jawa Timur, maka cenderung akan meningkatkan volume beras impor di provinsi Jawa Timur.

Kondisi tersebut dapat disebabkan karena dengan semakin meningkatnya harga dari ubi kayu menunjukkan bahwa pada saat itu jumlah ubi kayu mengalami penyusutan sehingga mendongkrak harga ubi kayu tersebut, sehingga konsumsi masyarakat akan terfokus pada beras. Apabila kondisi beras yang ada tidak dapat memenuhi permintaan dari masyarakat maka, solusi yang dapat di lakukan adalah dengan memanfaat beras impor tersebut. Ubi kayu yang merupakan barang subtitusi pengganti beras ini banyak dimanfaatkan sebagai makanan pokok oleh sebagian besar masyarakat di kabupaten Kediri, Nganjuk dan Trenggalek. Hal ini dilakukan sebagai upaya untuk mengatasi masalah ketersediaan pangan masyarakat ketika harga beras mengalami lonjakan yang cukup tinggi yakni dengan diolah menjadi tiwul atau gaplek.

Hasil penelitian ini sesuai dengan penelitian yang dilakukan oleh Astuti (2007) yang menyatakan bahwa
Indonesia terbukti masih terjadi aktivitas pengimporan beras meskipun tarif impor mengalami kenaikan, hal ini semakin membuktikan bahwa efisiensi produksi pangan di Indonesia masih rendah.

\section{PENUTUP}

\subsection{Simpulan}

Berdasarkan hasil pengujian dan pembahasan yang telah dijabarkan pada bab sebelumnya, maka kesimpulan yang dapat diambil dalam penelitian ini adalah

1. Terdapat perkembangan dari jumlah penduduk selama 15 tahun terakhir dengan rata - rata per tahun sebesar $0,10 \%$, produksi padi dengan rata rata per tahun sebesar $-0,44 \%$, harga beras lokal dengan rata - rata per tahun sebesar $10,76 \%$, harga jagung dengan rata - rata per tahun sebesar $8,78 \%$ dan harga ubi kayu dengan rata - rata per tahun sebesar $14,28 \%$ serta volume beras impor di Jawa Timur dengan rata-rata per tahun sebesar $11,46 \%$ meskipun perkembangan tersebut berfluktuatif.

2. Hanya variabel produksi padi dan harga beras lokal yang memiliki pengaruh signifikan terhadap volume beras impor, dimana untuk 
variabel produksi padi ditunjukkan dengan besarnya nilai $t_{\text {hitung }}$ yang diperoleh adalah -2,303 dengan taraf signifikan sebesar 0,047 dan untuk harga beras lokal yang ditunjukkan dengan besarnya nilai $t_{\text {hitung }}$ yang diperoleh adalah 5,680 dengan taraf signifikan sebesar 0,000. Hal tersebut dapat disebabkan karena apabila produksi padi melimpah dan harga beras lokal murah, maka pemerintah tidak akan mengambil langkah untuk melakukan impor beras.

3. Variabel harga beras lokal mempunyai pengaruh paling dominan terhadap volume beras impor di Jawa Timur, dimana hal tersebut ditunjukkan dengan nilai $\mathrm{t}_{\text {hitung }}$ yang diperoleh adalah 5,680 dengan taraf signifikan sebesar 0,000 yang lebih kecil dibandingkan dengan taraf signifikansi variabel lainnya. Hal tersebut dapat disebabkan karena semakin terjangkaunya harga beras lokal oleh seluruh lapisan masyarakat, maka minat masyarakat untuk mengkonsumsi beras impor juga akan semakin menurun, sehingga dapat meminimalisir volume beras impor di Jawa Timur.

\subsection{Saran}

Berdasarkan kesimpulan yang ada, maka saran yang diajukan dalam penelitian ini adalah :

1. Hendaknya pemerintah provinsi Jawa Timur melalui Dinas Pertanian Tanaman Pangan dan Badan Ketahanan Pangan Jatim dapat terus melakukan pengawasan sehingga dapat membatasi peredaran dan penggunaan beras impor.

2. Penelitian ini diharapkan dapat menjadi bahan informasi dan masukan bagi pemerintah daerah khususnya sebagai bahan pertimbangan dalam upaya memutuskan dan mengimplementasikan kebijakan impor beras. Agar tindakan tersebut tidak semakin memperburuk kondisi ketahan pangan di Provinsi Jawa Timur.

\section{DAFTAR PUSTAKA}

Afrianto, 2010, Analisis Pengaruh Stok Beras, Luas Panen, Rata-Rata Produksi, Harga Beras, dan Jumlah Konsumsi Beras Terhadap Ketahanan Pangan di Jawa Tengah, Penelitian Fakultas Ekonomi Universitas Diponegoro, Semarang. 
Firdaus. dan Prawiranegara, 2008, Analisis Faktor-Faktor Yang Mempengaruhi Produksi Dan Konsumsi Beras Di Kabupaten Siak, Riau. Fakultas Ekonomi dan Manajemen Institut Pertanian Bogor. Skripsi

Ghozali, 2006, Aplikasi Analisis Multivariate dengan Program SPSS, Badan Penerbit Universitas Diponegoro, Semarang

Hadi, dan Wiryono, 2005, Dampak Kebijakan Proteksi Terhadap Ekonomi Beras Di Indonesia, Jurnal Agro Ekonomi, Vol. 23, No. 2

Hardono, Rachman, Handewi, Hartini, 2004, liberalisasi perdagangan: sisi teori, dampak empiris dan perspektif ketahanan pangan, Forum Penelitian Agro Ekonomi. Vol. 22 No. 2

http://ekonomi.kompasiana.com/kompas /agrobisnis/2011/04/09/politikgabah-vs-gabah-politik/

http://bisniskeuangan.kompas.com/read/ 2011/01/11/02404686/Realisasi.Im por.Beras.2.16.Juta.Ton
Kurniawati dan Kamsiati, 2010, Pemanfaatan Ubi Kayu sebagai Bahan Pangan Non Beras dalam Mendukung Ketahanan Pangan di Kalimantan Tengah, Balai Pengkajian Teknologi Pertanian Kalimantan Tengah.

Lubis, 2005, Perencanaan Korporasi Peningkatan Ketahanan Pangan di Provinsi Sumatra Utara, Prosiding Seminar Sehari Strategi Penguatan Ketahanan Pangan, Medan

Malian, Mardianto, Ariani, 2004, Faktor-faktor yang mempengaruhi produksi, konsumsi, dan Harga Beras serta Inflasi Bahan Makanan, Jurnal Agro Ekonomi, Vol. 22, No. 2

Mubyarto, 2007, Kapitalisme dan UUD 45. Kompas,2007/03/12,Kompas Online

Nainggolan. 2000. Ekonomi Beras: Antara Proteksi dan Pasar Bebas. 10 April 2000.

Pakpahan; Handewi; dan Suhartini. 2003. Penelitian tentang Ketahanan Pangan Masyarakat Berpendapatan Rendah. Monograph Series 14. PSE, Bogor. 
Putong, 2003, Ketahanan Pangan

Berbasis Produksi dan

Kesejahteraan Petani. Ilmu

Pertanian Vol. 12 No.2, 2005 :

152-164, Fakultas Pertanian UGM

dan MMA-UGM. Yogyakarta

Saifullah. 2001. Kebijaksanaan Harga

Dasar atau Harga Pembelian

Pemerintah? http://bulog.co.id.

/papers/agus_02222001.html.

Saragih, 2001, Pembangunan Pertanian, Departemen Pertanian, Jakarta

Sitanggang dan Burhan, 2007. Perspektif Pangan Masa Depan (http://sinarharapan.co.id: diakses 15 Desember 2009)

Sugema, 2006, Krisis Kebijakan Beras, Aplikasi dan Teori, Rajawali, Jakarta

Suharjo, 2008, Perencanaan Pangan dan Gizi. Bumi Aksara. Bogor

Sumarsono, 2002, Metode Penelitian Akuntansi, Penerbit UPN "Veteran" Jawa Timur. 